\title{
Determination of DNA Damage in Floriculturists Exposed to Mixtures of Pesticides
}

\author{
J. Castillo-Cadena, ${ }^{1,2}$ L. E. Tenorio-Vieyra, ${ }^{2}$ A. I. Quintana-Carabia, ${ }^{2}$ M. M. García-Fabila, ${ }^{2}$ \\ E. Ramírez-San Juan, ${ }^{1}$ and E. Madrigal-Bujaidar ${ }^{1,3}$ \\ ${ }^{1}$ Escuela Nacional de Ciencias Biológicas, Instituto Politécnico Nacional (IPN), Universidad Autónoma del Estado de México, México \\ ${ }^{2}$ Facultad de Química, Universidad Autónoma del Estado de México, México \\ ${ }^{3}$ Laboratorio de Genética, Escuela Nacional de Ciencias Biologicas, Instituto Politécnico Nacional (IPN), \\ Prolongación de Carpio y Plan de Ayala s/n, Santo Tomás, CP 11340, México, DF, México
}

Received 5 April 2005; Revised 18 October 2005; Accepted 19 October 2005

\begin{abstract}
The aim of the study was to determine possible DNA damage in floriculturists chronically exposed to pesticides. Leukocytes from 52 workers, 46 environmentally exposed, and 38 control individuals were evaluated with the comet assay. Serum from all individuals was also analyzed for pesticides using gas chromatography coupled to mass spectrometry. A statistically significant difference in DNA fragmentation in the pesticide exposed group compared to the other two groups $(\mathrm{P}<.001)$ was found. No differences between environmentally exposed and control individuals were detected. The statistical analysis showed no significant correlation between DNA damage and sex, age, drinking or smoking habits, as well as years of exposure. One or more pesticides were detected in $50 \%$ of the floriculturists, while in the rest of the individuals, a chemical related with the preparation of pesticides, such as additives, plasticizers, or solvents, was found. Our study shows that chronic exposure to pesticides produces DNA damage in floriculturists. It also suggests that this type of monitoring could be valuable in recommending preventive measures.
\end{abstract}

Copyright (c) 2006 J. Castillo-Cadena et al. This is an open access article distributed under the Creative Commons Attribution License, which permits unrestricted use, distribution, and reproduction in any medium, provided the original work is properly cited.

\section{INTRODUCTION}

Man is exposed to a great deal of environmental harm that may affect the functioning of specific biomolecules and thereby damage health at various levels. On the other hand, DNA alterations are known to be indicators of early damage in the affected organisms; consequently, identifying the genotoxic potential of xenobiotics has been an effective and beneficial strategy for risk assessment [1]. However, the adoption of preventive measures is probably more difficult regarding chemicals such as pesticides which are strongly related with a number of human activities as agriculture, aquaculture, or several household tasks. Likewise, the diversity of commercial products makes it easy to exchange one for another or to mix them so as to increase their efficacy.

Most experimental studies on the genotoxic potential of pesticides have been made with a single compound. Although the results have varied, more positive data have been published regarding chemicals that have been evaluated with a variety of test models ranging from bacteria to human cells, using genic and cytogenetic endpoints $[2,3]$. Controversial data on a single compound make it more difficult to reach a conclusion on the genotoxicity of the pesticide; for example, Debuyst and Van Larekebe [4] reported an increase in the rate of sister chromatid exchanges (SCEs) induced by methomyl in human leukocytes while Bonatti et al [5] found the opposite result with the same compound.

Studies made in human populations exposed to pesticides have also revealed conflicting results. In the case of floriculturists in particular, approximately 12 studies have been reported, most of which presented positive results when the rate of chromosomal aberrations, SCE or micronuclei was evaluated $[6,7]$, while two studies showed negative data $[6,8]$. As regards the use of the single cell electrophoresis (comet assay), a study made on Greek farmers working with ornamental plants as well as vegetables indicated no statistically significant differences in the DNA damage between the examined groups [9].

The previous data suggest that intrinsic and extrinsic factors could be involved in the effect of pesticides on the genetic material, and thus support the relevance of monitoring specific populations to determine the potential genotoxic damage produced by these chemicals. The aim of this investigation was, therefore, to determine whether Mexican 
floriculturists exposed to mixtures of pesticides for several years showed alterations in their DNA integrity, measuring this with the comet assay. This method mainly reveals single or double DNA strand breaks and alkali-labile sites, and has been successfully used in populations exposed to various xenobiotics [10]. We considered that results obtained with this assay could be helpful in providing advice concerning the application of preventive measures. An additional step was the analytical determination of a number of pesticides in the serum of the studied populations.

\section{MATERIALS AND METHODS}

\section{Characteristics of the studied population}

The study was made on residents of Santa Maria Aransazú, a village of 3000 people located $100 \mathrm{~km}$ south of Mexico city, where more than $50 \%$ of the population works in floriculture activities. Their production includes at least 13 different kinds of flowers, such as roses, chrysanthemums, carnations, gladioluses, nards, daisies, and lilies.

A questionnaire was applied to the participants in the study to determine personal data and habits, as well as their health and work status. A hematological test was also applied to the participants to verify that they were clinically healthy and that they had taken no medication for at least two months before the time of sampling. An informed consent was also obtained from each participant, as well as the approval of the Board of the Medico-Biological Program, National Polytechnic Institute, and of the Board of Research, University of the State of Mexico. The investigation was made on 52 floriculturists (most of them males) with a mean age of 27 years, who had been working for at least two years (range from 2 to 48 years) preparing the mixtures of pesticides and spraying them in the greenhouses, two or three times a week. The pertinent data of the groups studied are indicated in Table 1. The floriculturists were exposed to mixtures of chemicals which belong to organochlorates, organophosphates, piretroides, and carbamates. The protective devices and clothing used by the workers included gloves, masks, boots, and overalls: $3.8 \%$ of the individuals wore all four pieces, $9.6 \%$ wore three of them, $19.2 \%$ wore two, and $25 \%$ wore only one of them, usually gloves or boots. Another group of 46 individuals who had been environmentally exposed was included in the study. This second group was constituted by vendors of the local market who live in the village but did not handle pesticides. Finally, the control population consisted of 38 persons that were students and administrative employees of a nearby university.

\section{CHEMICALS AND BLOOD SAMPLING}

The following chemicals were purchased from Sigma Chemicals (St Louis, Mo, USA): dimethyl sulfoxide (DMSO), triton $\mathrm{X}-100$, EDTA, normal melting point agarose (NMPA), low melting point agarose (LMPA), ethidium bromide, trizma base, and PBS. Methanol and ethyl acetate (HPLC grade) were obtained from Honeywell International Inc (Muskegon, Mich, USA).
Blood samples $(6 \mathrm{~mL})$ were taken from each of five individuals from each group, every Tuesday morning (7-8 AM). One $\mathrm{mL}$ was placed in a coated heparinized tube and transported on ice to the laboratory to be processed with the comet assay within $1 \mathrm{~h}$. The serum of the other $5 \mathrm{~mL}$ was immediately frozen at $-70^{\circ} \mathrm{C}$ until time for the pesticide to be identified (within a month). For the data analysis, the slides and serum samples were codified; decodification was done after the genotoxic and chromatographic determinations had been made by one investigator and reviewed by another.

\section{Comet assay}

The alkaline comet procedure was performed as previously described [11, 12]. Briefly, fully frosted slides were layered with NMPA and dried; then, $100 \mu \mathrm{L}$ of LMPA were mixed with $50 \mu \mathrm{L}$ of whole blood and applied as a second layer onto the precoated slides; finally, a third layer of LMPA was added on top. The slides were placed in freshly prepared lysing solution for $24 \mathrm{~h}$ at $4^{\circ} \mathrm{C}$ to leave the DNA uncovered. The solution consisted of NaCL 2.5 M, EDTA $100 \mathrm{mM}$, trizma base $10 \mathrm{mM}$ ( $\mathrm{pH} 10$ ), 1\% triton X-100, and 10\% DMSO. Next, the slides were immersed in alkaline buffer $(\mathrm{NaOH} 300 \mathrm{mM}$ and EDTA $1 \mathrm{mM}, \mathrm{pH}>13$ ) for $30 \mathrm{~min}$, to allow the unwinding of DNA. Electrophoresis was conducted for $20 \mathrm{~min}$ at $25 \mathrm{~V}(0.66 \mathrm{~V} / \mathrm{cm})$ and $30 \mathrm{~mA}$ at the same $\mathrm{pH}$. The slides were then placed in neutralizing buffer $(\mathrm{pH} 7.5)$ three times each for $5 \mathrm{~min}$, and dried at room temperature. Finally, the slides were stained with $50 \mu \mathrm{L}$ of ethidium bromide for $1 \mathrm{~min}$. The stained nucleoids were examined at 40X in an epifluorescent microscope (Axiophot-1 Zeiss) with a digital camera (ZWS$47 \mathrm{DE}$ ), adapted to software for the capture, processing, and image analysis (Zeiss KS400 version 3.01). One hundred nucleoids per individual were observed to determine the lengthto-width index (T/N index), which was obtained by measuring the image length and dividing the result by the head diameter. We also determined the percentage of cells with DNA migration verses the percentage of those without migration in 100 cells per individual. The latter type corresponded to cells with intact nuclei and no DNA displacement.

The Kruskall-Wallis and Dunn tests were used to evaluate the statistical significance of the difference in the medians of the $\mathrm{T} / \mathrm{N}$ index obtained for the exposed and control groups, as well as of the difference in the percentage of cells with DNA migration among the three groups. A linear regression analysis was also made to determine the correlation between the $\mathrm{T} / \mathrm{N}$ values and the percentage of cells with DNA migration. Moreover, we determined the intercelular dispersion of the comet values in the groups studied by calculating the dispersion coefficient $(\mathrm{H})$ [13].

Also, the correlation between the comet data, and the age and work years was evaluated by applying a Pearson's correlation test. Differences were considered significant when the $\mathrm{P}$ value was .05 or less (two-tailed). The statistical analyses were carried out using the Sigma Stat 2.03 statistical package.

On the other hand, we utilized a general linear model procedure with a normal distribution using a SAS 9.1 statistical software package to determine the relationship of personal variables, such as sex, smoking, and drinking, on the 
TABLE 1: Individual characteristics of the study groups.

\begin{tabular}{|c|c|c|c|c|c|c|}
\hline Subject & $\begin{array}{l}\text { Studied groups } \\
(0=\text { control } \\
1=\text { vendors } \\
2=\text { floriculturists })\end{array}$ & Age (years) & $\begin{array}{l}\text { Exposure time } \\
\text { (years) }\end{array}$ & $\begin{array}{c}\text { Sex } \\
(\mathrm{M}=\text { male } \\
\mathrm{F}=\text { female })\end{array}$ & $\begin{array}{l}\text { Drinking habits } \\
(1=\text { drinker } \\
0=\text { nondrinker })\end{array}$ & $\begin{array}{l}\text { Smoking habits } \\
(1=\text { smoker } \\
0=\text { nonsmoker })\end{array}$ \\
\hline 1 & 0 & 42 & 0 & $\mathrm{M}$ & 1 & 1 \\
\hline 2 & 0 & 37 & 0 & $\mathrm{~F}$ & 0 & 1 \\
\hline 3 & 0 & 46 & 0 & $\mathrm{~F}$ & 0 & 0 \\
\hline 4 & 0 & 50 & 0 & $\mathrm{~F}$ & 0 & 0 \\
\hline 5 & 0 & 23 & 0 & $\mathrm{~F}$ & 0 & 0 \\
\hline 6 & 0 & 22 & 0 & $\mathrm{~F}$ & 0 & 0 \\
\hline 7 & 0 & 24 & 0 & M & 0 & 0 \\
\hline 8 & 0 & 23 & 0 & M & 0 & 0 \\
\hline 9 & 0 & 23 & 0 & $\mathrm{~F}$ & 0 & 0 \\
\hline 10 & 0 & 21 & 0 & M & 1 & 1 \\
\hline 11 & 0 & 22 & 0 & M & 0 & 0 \\
\hline 12 & 0 & 19 & 0 & M & 0 & 0 \\
\hline 13 & 0 & 39 & 0 & M & 0 & 0 \\
\hline 14 & 0 & 23 & 0 & M & 0 & 0 \\
\hline 15 & 0 & 19 & 0 & $\mathrm{~F}$ & 0 & 0 \\
\hline 16 & 0 & 37 & 0 & F & 0 & 0 \\
\hline 17 & 0 & 48 & 0 & $\mathrm{~F}$ & 0 & 0 \\
\hline 18 & 0 & 18 & 0 & M & 1 & 1 \\
\hline 19 & 0 & 21 & 0 & M & 0 & 1 \\
\hline 20 & 0 & 39 & 0 & $\mathrm{~F}$ & 0 & 0 \\
\hline 21 & 0 & 25 & 0 & M & 0 & 0 \\
\hline 22 & 0 & 36 & 0 & M & 1 & 1 \\
\hline 23 & 0 & 31 & 0 & M & 0 & 1 \\
\hline 24 & 0 & 29 & 0 & $\mathrm{~F}$ & 0 & 0 \\
\hline 25 & 0 & 30 & 0 & $\mathrm{~F}$ & 1 & 1 \\
\hline 26 & 0 & 24 & 0 & $\mathrm{M}$ & 1 & 0 \\
\hline 27 & 0 & 42 & 0 & $\mathrm{~F}$ & 0 & 0 \\
\hline 28 & 0 & 24 & 0 & $M$ & 0 & 1 \\
\hline 29 & 0 & 32 & 0 & $\mathrm{M}$ & 1 & 0 \\
\hline 30 & 0 & 47 & 0 & $\mathrm{~F}$ & 0 & 1 \\
\hline 31 & 0 & 32 & 0 & $\mathrm{M}$ & 0 & 0 \\
\hline 32 & 0 & 40 & 0 & $\mathrm{~F}$ & 1 & 1 \\
\hline 33 & 0 & 20 & 0 & $\mathrm{M}$ & 0 & 0 \\
\hline 34 & 0 & 20 & 0 & $\mathrm{M}$ & 0 & 0 \\
\hline 35 & 0 & 20 & 0 & $\mathrm{M}$ & 1 & 0 \\
\hline 36 & 0 & 21 & 0 & $\mathrm{M}$ & 0 & 0 \\
\hline 37 & 0 & 21 & 0 & $\mathrm{M}$ & 1 & 1 \\
\hline 38 & 0 & 21 & 0 & $\mathrm{~F}$ & 1 & 0 \\
\hline 39 & 1 & 36 & 0 & $\mathrm{M}$ & 0 & 0 \\
\hline 40 & 1 & 19 & 0 & $\mathrm{~F}$ & 1 & 1 \\
\hline 41 & 1 & 41 & 0 & $\mathrm{M}$ & 0 & 1 \\
\hline 42 & 1 & 67 & 0 & $\mathrm{~F}$ & 0 & 0 \\
\hline 43 & 1 & 53 & 0 & $\mathrm{~F}$ & 0 & 0 \\
\hline 44 & 1 & 62 & 0 & $\mathrm{M}$ & 0 & 0 \\
\hline 45 & 1 & 21 & 0 & $\mathrm{~F}$ & 1 & 0 \\
\hline 46 & 1 & 32 & 0 & $\mathrm{~F}$ & 0 & 0 \\
\hline 47 & 1 & 41 & 0 & $\mathrm{~F}$ & 0 & 0 \\
\hline 48 & 1 & 63 & 0 & $\mathrm{~F}$ & 0 & 0 \\
\hline 49 & 1 & 67 & 0 & $\mathrm{~F}$ & 1 & 0 \\
\hline 50 & 1 & 33 & 0 & $\mathrm{M}$ & 1 & 0 \\
\hline
\end{tabular}


TABle 1: Continued.

\begin{tabular}{|c|c|c|c|c|c|c|}
\hline Subject & $\begin{array}{l}\text { Studied groups } \\
(0=\text { control } \\
1=\text { vendors } \\
2=\text { floriculturists })\end{array}$ & Age (years) & $\begin{array}{l}\text { Exposure time } \\
\text { (years) }\end{array}$ & $\begin{array}{c}\text { Sex } \\
(\mathrm{M}=\text { male } \\
\mathrm{F}=\text { female })\end{array}$ & $\begin{array}{l}\text { Drinking habits } \\
(1=\text { drinker } \\
0=\text { nondrinker })\end{array}$ & $\begin{array}{l}\text { Smoking habits } \\
(1=\text { smoker } \\
0=\text { nonsmoker })\end{array}$ \\
\hline 51 & 1 & 52 & 0 & $\mathrm{~F}$ & 0 & 0 \\
\hline 52 & 1 & 64 & 0 & $\mathrm{~F}$ & 1 & 0 \\
\hline 53 & 1 & 35 & 0 & $\mathrm{~F}$ & 1 & 0 \\
\hline 54 & 1 & 31 & 0 & $\mathrm{~F}$ & 1 & 0 \\
\hline 55 & 1 & 58 & 0 & $\mathrm{~F}$ & 1 & 0 \\
\hline 56 & 1 & 64 & 0 & $\mathrm{~F}$ & 1 & 0 \\
\hline 57 & 1 & 55 & 0 & $\mathrm{~F}$ & 0 & 0 \\
\hline 58 & 1 & 24 & 0 & $\mathrm{~F}$ & 1 & 0 \\
\hline 59 & 1 & 68 & 0 & $\mathrm{M}$ & 0 & 0 \\
\hline 60 & 1 & 24 & 0 & $\mathrm{~F}$ & 0 & 0 \\
\hline 61 & 1 & 65 & 0 & $\mathrm{~F}$ & 1 & 0 \\
\hline 62 & 1 & 51 & 0 & $\mathrm{~F}$ & 1 & 0 \\
\hline 63 & 1 & 28 & 0 & $\mathrm{~F}$ & 1 & 0 \\
\hline 64 & 1 & 27 & 0 & $\mathrm{~F}$ & 1 & 0 \\
\hline 65 & 1 & 54 & 0 & $\mathrm{~F}$ & 0 & 0 \\
\hline 66 & 1 & 42 & 0 & $\mathrm{~F}$ & 0 & 0 \\
\hline 67 & 1 & 44 & 0 & $\mathrm{~F}$ & 0 & 0 \\
\hline 68 & 1 & 54 & 0 & $\mathrm{~F}$ & 1 & 0 \\
\hline 69 & 1 & 41 & 0 & $\mathrm{~F}$ & 0 & 0 \\
\hline 70 & 1 & 27 & 0 & $\mathrm{M}$ & 1 & 0 \\
\hline 71 & 1 & 54 & 0 & $\mathrm{~F}$ & 1 & 0 \\
\hline 72 & 1 & 38 & 0 & $\mathrm{M}$ & 1 & 0 \\
\hline 73 & 1 & 24 & 0 & $\mathrm{~F}$ & 1 & 0 \\
\hline 74 & 1 & 18 & 0 & $\mathrm{~F}$ & 1 & 0 \\
\hline 75 & 1 & 29 & 0 & $\mathrm{~F}$ & 1 & 0 \\
\hline 76 & 1 & 114 & 0 & $\mathrm{~F}$ & 1 & 0 \\
\hline 77 & 1 & 53 & 0 & $\mathrm{~F}$ & 1 & 0 \\
\hline 78 & 1 & 21 & 0 & $\mathrm{~F}$ & 0 & 0 \\
\hline 79 & 1 & 54 & 0 & $\mathrm{~F}$ & 0 & 0 \\
\hline 80 & 1 & 40 & 0 & $\mathrm{M}$ & 1 & 0 \\
\hline 81 & 1 & 62 & 0 & $\mathrm{~F}$ & 0 & 0 \\
\hline 82 & 1 & 45 & 0 & $\mathrm{~F}$ & 1 & 0 \\
\hline 83 & 1 & 36 & 0 & $\mathrm{~F}$ & 1 & 0 \\
\hline 84 & 1 & 21 & 0 & $\mathrm{~F}$ & 0 & 0 \\
\hline 85 & 2 & 35 & 20 & $\mathrm{M}$ & 1 & 1 \\
\hline 86 & 2 & 31 & 13 & M & 0 & 0 \\
\hline 87 & 2 & 38 & 11 & $\mathrm{M}$ & 1 & 1 \\
\hline 88 & 2 & 37 & 25 & $\mathrm{M}$ & 1 & 1 \\
\hline 89 & 2 & 33 & 18 & $\mathrm{M}$ & 0 & 1 \\
\hline 90 & 2 & 24 & 12 & $\mathrm{~F}$ & 1 & 0 \\
\hline 91 & 2 & 18 & 2 & $\mathrm{~F}$ & 1 & 0 \\
\hline 92 & 2 & 22 & 5 & $\mathrm{~F}$ & 0 & 0 \\
\hline 93 & 2 & 37 & 5 & $\mathrm{~F}$ & 1 & 0 \\
\hline 94 & 2 & 24 & 2 & $\mathrm{M}$ & 1 & 0 \\
\hline 95 & 2 & 22 & 2 & $\mathrm{M}$ & 1 & 0 \\
\hline 96 & 2 & 21 & 4 & $\mathrm{~F}$ & 1 & 0 \\
\hline 97 & 2 & 33 & 13 & $\mathrm{M}$ & 1 & 1 \\
\hline 98 & 2 & 35 & 20 & $\mathrm{M}$ & 1 & 0 \\
\hline 99 & 2 & 41 & 10 & $\mathrm{~F}$ & 1 & 0 \\
\hline 100 & 2 & 32 & 20 & $\mathrm{M}$ & 1 & 0 \\
\hline
\end{tabular}


TABle 1: Continued.

\begin{tabular}{|c|c|c|c|c|c|c|}
\hline Subject & $\begin{array}{l}\text { Studied groups } \\
(0=\text { control } \\
1=\text { vendors } \\
2=\text { floriculturists })\end{array}$ & Age (years) & $\begin{array}{l}\text { Exposure time } \\
\text { (years) }\end{array}$ & $\begin{array}{c}\text { Sex } \\
(\mathrm{M}=\text { male } \\
\mathrm{F}=\text { female })\end{array}$ & $\begin{array}{l}\text { Drinking habits } \\
(1=\text { drinker } \\
0=\text { nondrinker })\end{array}$ & $\begin{array}{l}\text { Smoking habits } \\
(1=\text { smoker } \\
0=\text { nonsmoker })\end{array}$ \\
\hline 101 & 2 & 30 & 15 & $\mathrm{M}$ & 1 & 1 \\
\hline 102 & 2 & 25 & 15 & M & 1 & 1 \\
\hline 103 & 2 & 18 & 2 & $\mathrm{~F}$ & 0 & 0 \\
\hline 104 & 2 & 45 & 30 & M & 1 & 1 \\
\hline 105 & 2 & 66 & 30 & M & 1 & 1 \\
\hline 106 & 2 & 16 & 2 & M & 1 & 1 \\
\hline 107 & 2 & 36 & 62 & M & 1 & 0 \\
\hline 108 & 2 & 25 & 15 & M & 1 & 1 \\
\hline 109 & 2 & 45 & 32 & M & 1 & 0 \\
\hline 110 & 2 & 60 & 48 & M & 1 & 0 \\
\hline 111 & 2 & 24 & 14 & M & 1 & 0 \\
\hline 112 & 2 & 14 & 3 & $\mathrm{~F}$ & 0 & 0 \\
\hline 113 & 2 & 14 & 3 & $\mathrm{~F}$ & 0 & 0 \\
\hline 114 & 2 & 12 & 2 & $\mathrm{M}$ & 1 & 0 \\
\hline 115 & 2 & 37 & 12 & $\mathrm{M}$ & 1 & 0 \\
\hline 116 & 2 & 29 & 13 & $\mathrm{~F}$ & 1 & 0 \\
\hline 117 & 2 & 14 & 3 & $\mathrm{~F}$ & 0 & 0 \\
\hline 118 & 2 & 20 & 12 & $\mathrm{M}$ & 1 & 1 \\
\hline 119 & 2 & 38 & 18 & $\mathrm{M}$ & 1 & 1 \\
\hline 120 & 2 & 42 & 35 & $\mathrm{M}$ & 0 & 0 \\
\hline 121 & 2 & 20 & 5 & $\mathrm{M}$ & 1 & 1 \\
\hline 122 & 2 & 18 & 3 & $\mathrm{M}$ & 0 & 1 \\
\hline 123 & 2 & 16 & 4 & $\mathrm{M}$ & 1 & 1 \\
\hline 124 & 2 & 16 & 2 & $\mathrm{M}$ & 0 & 0 \\
\hline 125 & 2 & 25 & 11 & $\mathrm{M}$ & 1 & 1 \\
\hline 126 & 2 & 21 & 13 & $\mathrm{M}$ & 1 & 1 \\
\hline 127 & 2 & 30 & 20 & $\mathrm{M}$ & 0 & 1 \\
\hline 128 & 2 & 51 & 20 & $\mathrm{M}$ & 1 & 1 \\
\hline 129 & 2 & 18 & 11 & $\mathrm{M}$ & 1 & 1 \\
\hline 130 & 2 & 19 & 4 & $\mathrm{~F}$ & 0 & 1 \\
\hline 131 & 2 & 24 & 10 & $\mathrm{~F}$ & 1 & 0 \\
\hline 132 & 2 & 44 & 26 & $\mathrm{~F}$ & 0 & 0 \\
\hline 133 & 2 & 15 & 2 & $\mathrm{~F}$ & 0 & 0 \\
\hline 134 & 2 & 47 & 37 & $\mathrm{M}$ & 1 & 0 \\
\hline 135 & 2 & 19 & 4 & $\mathrm{M}$ & 1 & 0 \\
\hline 136 & 2 & 39 & 25 & $\mathrm{M}$ & 1 & 0 \\
\hline
\end{tabular}

DNA damage (logarithmically transformed) induced by the exposure to pesticides (Bonassi et al) [14].

\section{Chromatographic assay}

For the chromatographic assay, we selected seven pesticides used by the workers, to determine the presence of these chemicals or of their residues: methomyl, methamidophos, monocrotophos, carbofuram, maneb, lindane, and methyl paration. The effectiveness of the procedure to extract and identify the chemicals in serum was initially determined for each pesticide separately, and then, the process was established for the mixture. For the assay, we followed the method of Lacassie et al [15]. Briefly, $2 \mathrm{ml}$ of the serum samples were placed on an Oasis hydrophilic-lipophilic balanced copolimer cartridge (Waters, Guyacourt, France) previously treated with methanol and deionized water. The samples were washed with deionized water at vacuum, centrifuged at $4000 \mathrm{rpm}$ for $3 \mathrm{~min}$, eluted with $3 \mathrm{~mL}$ of ethyl acetate, and evaporated in a nitrogen atmosphere at $40^{\circ} \mathrm{C}$. The residue was diluted with $100 \mu \mathrm{L}$ of ethyl acetate, and $1 \mu \mathrm{L}$ of this solution was injected to a gas chromatograph (Varian 3400) coupled to a mass spectrometer (Saturno II). The chromatograph was equipped with a Restek RTX-5 MS column (internal diameter $30 \mathrm{~m} \times 0.25 \mathrm{~mm}$; phase, $0.1 \mu \mathrm{m}$ ) (Supelco, St Quentin-Fallavier, France). The apparatus was programmed for an initial temperature of $60^{\circ} \mathrm{C}$, rising to $300^{\circ} \mathrm{C}$ at the rate of $10^{\circ} \mathrm{C} / \mathrm{min}$. Helium was used as the carrier gas with a flow 


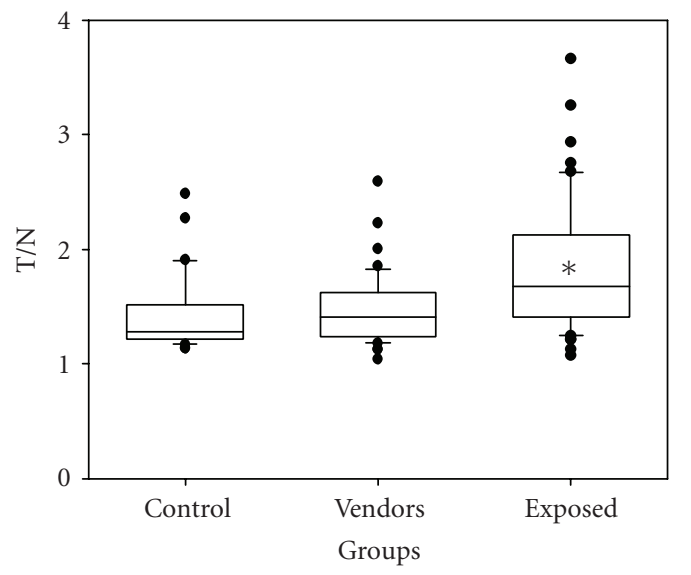

Figure 1: Box plot of the T/N index values obtained in the lymphocytes of the studied groups. Each box encloses $50 \%$ of the data with the median value of the variable displayed as a line. The height of the box is the interquartile range (IQR) of the variable population. The lines from the top and the bottom of each box mark the $\pm 1.5 \mathrm{IQR}$ value. The outliers are displayed as individual points. ${ }^{*}$ Statistically significant difference with respect to control and vendors groups. Kruskal Wallis test $(\mathrm{P}<.001)$.

rate of $1 \mathrm{~mL} / \mathrm{min}$. The mass spectrometer was adjusted to 40 $500 \mathrm{~m} / \mathrm{z}$ interval of reading, with a $4 \mathrm{~min}$ of inhibited detection, using an electronic impact $(70 \mathrm{eV})$. A chromatogram was obtained from each sample, and each compound was identified by means of the NIST 98 electronic library of the equipment, which keeps 62000 mass spectra.

\section{RESULTS}

Figure 1 shows a box-plot representation of the T/N index in leukocytes of the controls and exposed individuals. The height of the box represents the interquartile range, that is, the range of values that excludes $25 \%$ of the uppermost and lowest values of the distribution. A T/N median value of 1.29 was observed in the control individuals and one of 1.40 in the environmentally exposed group, showing no statistical difference between the two groups. However, the pesticide exposed workers, with a median $\mathrm{T} / \mathrm{N}$ index of 1.67 , had statistically significant DNA damage in comparison with the level found in the other two groups $(H=20.81, \mathrm{P}<.001)$. The DNA damage determined in the floriculturists was $16.11 \%$ higher than that found in the vendors, and 22.9\% higher with respect to the control group. Moreover, our results showed that the floriculturists had values of the $\mathrm{T} / \mathrm{N}$ index $76 \%$ higher than 1.5, while the vendors and the control individuals had values $21 \%$ and $24 \%$ higher, respectively. A detailed description of individual data is shown in Table 2. It is pertinent to note that the determined DNA damage may indicate the effect mainly on lymphocytes, which are long-lived cells with high sensitivity to chemical agents, and may accumulate DNA damage and mutations over time $[16,17]$, to a lesser extent such damage may suggest an effect on granulocytes, which are short-lived cells that possess antioxidant enzymes [17].

The results obtained with respect to the percentage of damaged cells agree with the previous determination: we found a significant difference between the value detected in the floriculturists and that obtained in the other two groups $(H=23.70, \mathrm{P}<.001)$. Moreover, both types of evaluations were congruent showing a correlation coefficient ( $\mathrm{r}$ ) of 0.96 , 0.93 , and 0.91 in the control group, the vendors, and the floriculturists, respectively (Figure 2). The results obtained for the dispersion coefficient were $0.174,0.062$, and 0.184 , for the control individuals, vendors, and floriculturists. The analysis with the Mann-Whitney test showed a statistical difference in the group of vendors with respect to the other two groups. This means there was heterogeneous intercellular dispersion in the control and in the workers, as well as lower dispersion in the vendors. Figure 2 also shows that comet values for the vendors are somewhat less dispersed than those observed for the other groups. With respect to the comet data, we found that the control group had a low number of cells with intercellular dispersion and a low number of cells with slight DNA displacement. However, in the floriculturists the number of cells with intercellular dispersion was high, and with respect to the control group, the number of cells with DNA displacement was higher and the DNA displacement was greater.

The effect of variables, such as sex and age, as well as smoking and drinking habits and the exposure years, was evaluated in the three groups with respect to the comet values. Except for the smoking and drinking practice in the vendors, we found no relationship of the variables in any of the groups, as the results in Table 3 show. The data on drinking in the vendors could reveal an influence in the increase of DNA damage found with respect to the level observed in the control group, the information on smoking may be irrelevant because of the small number of smokers in the vendors group. However, this conclusion should be considered carefully in light of the heterogeneous matching of the demographic characteristics in the studied individuals. With respect to the use of protective devices and clothing, no correlation was detected with the comet values.

In the chromatographic determination, we found no pesticides or related chemicals in either the vendors or the control groups. However, chromatograms of $50 \%$ of the floriculturists indicated the presence of one or more pesticides, or their residues. Table 4 shows that most of the compounds identified were insecticides and fungicides. Moreover, in these same individuals as well as in the other 50\% of this group, we found the presence of dimethyl phthalate, bis (2-ethylhexil) phthalate, and dibutyl phthalate, chemicals that are used in the composition of pesticides. Besides these, we also determined xylene, cyclohexanone, and acetic acid, 2-ethylhexilester, which are additives used in pesticide formulation [18]. Other pesticides reported by the workers were chemicals such as benomyl and methomyl, however, these were not detected in our analysis. Our findings related with the presence in individuals of various chemicals used in the formulation of pesticides suggest that the undetected 
TABLE 2: Comet data, cells with DNA migration, and dispersion coefficient values $(\mathrm{H})$ of the study groups.

\begin{tabular}{|c|c|c|c|c|c|c|}
\hline Subject & $\begin{array}{l}\text { Studied groups } \\
(0=\text { control } \\
1=\text { vendors } \\
2=\text { floriculturists })\end{array}$ & $\begin{array}{l}\text { Length } \\
(\mu \mathrm{m})\end{array}$ & $\begin{array}{l}\text { Width } \\
(\mu \mathrm{m})\end{array}$ & $\begin{array}{l}\mathrm{T} / \mathrm{N} \\
\text { index }\end{array}$ & $\begin{array}{l}\text { Cells with } \\
\text { migration } \\
(\%)\end{array}$ & $\mathrm{H}$ \\
\hline 1 & 0 & 35.16 & 22.79 & 1.54 & 4 & 0.175 \\
\hline 2 & 0 & 30.76 & 27.79 & 1.21 & 0 & 0.174 \\
\hline 3 & 0 & 44.72 & 23.45 & 1.91 & 44 & 0.172 \\
\hline 4 & 0 & 47.78 & 25.15 & 1.9 & 32 & 0.172 \\
\hline 5 & 0 & 30.73 & 25.27 & 1.21 & 0 & 0.165 \\
\hline 6 & 0 & 32.77 & 25.76 & 1.27 & 0 & 0.178 \\
\hline 7 & 0 & 34.74 & 25.79 & 1.34 & 2 & 0.173 \\
\hline 8 & 0 & 32.19 & 25.84 & 1.24 & 0 & 0.158 \\
\hline 9 & 0 & 27.76 & 21.31 & 1.3 & 0 & 0.168 \\
\hline 10 & 0 & 31.2 & 24.26 & 1.28 & 0 & 0.181 \\
\hline 11 & 0 & 32.19 & 23.76 & 1.35 & 0 & 0.171 \\
\hline 12 & 0 & 28.72 & 22.33 & 1.28 & 0 & 0.178 \\
\hline 13 & 0 & 42.11 & 24.44 & 1.72 & 16 & 0.159 \\
\hline 14 & 0 & 32.79 & 23.78 & 1.38 & 4 & 0.168 \\
\hline 15 & 0 & 30.34 & 24.3 & 1.24 & 2 & 0.188 \\
\hline 16 & 0 & 31.19 & 27.23 & 1.14 & 4 & 0.185 \\
\hline 17 & 0 & 43.57 & 24.26 & 1.79 & 34 & 0.194 \\
\hline 18 & 0 & 52.77 & 23.25 & 2.27 & 56 & 0.173 \\
\hline 19 & 0 & 38.59 & 22.31 & 1.73 & 26 & 0.176 \\
\hline 20 & 0 & 29.27 & 23.29 & 1.25 & 4 & 0.172 \\
\hline 21 & 0 & 30.2 & 25.79 & 1.17 & 0 & 0.180 \\
\hline 22 & 0 & 30.4 & 20.39 & 1.49 & 8 & 0.183 \\
\hline 23 & 0 & 31.7 & 21.31 & 1.48 & 8 & 0.193 \\
\hline 24 & 0 & 35.59 & 22.47 & 1.58 & 10 & 0.164 \\
\hline 25 & 0 & 93.8 & 23.87 & 3.93 & 98 & 0.175 \\
\hline 26 & 0 & 30.4 & 23.78 & 1.27 & 2 & 0.173 \\
\hline 27 & 0 & 31.19 & 27.23 & 1.14 & 0 & 0.167 \\
\hline 28 & 0 & 26.77 & 22.28 & 1.2 & 0 & 0.165 \\
\hline 29 & 0 & 30.71 & 25.76 & 1.19 & 0 & 0.176 \\
\hline 30 & 0 & 35.67 & 24.38 & 1.46 & 10 & 0.182 \\
\hline 31 & 0 & 51.33 & 20.7 & 2.48 & 66 & 0.192 \\
\hline 32 & 0 & 30.4 & 20.39 & 1.49 & 8 & 0.170 \\
\hline 33 & 0 & 31.75 & 25.74 & 1.23 & 0 & 0.169 \\
\hline 34 & 0 & 32.77 & 25.76 & 1.27 & 0 & 0.176 \\
\hline 35 & 0 & 31.20 & 24.76 & 1.26 & 0 & 0.175 \\
\hline 36 & 0 & 31.69 & 26.81 & 1.18 & 0 & 0.174 \\
\hline 37 & 0 & 30.76 & 25.27 & 1.21 & 0 & 0.172 \\
\hline 38 & 0 & 32.18 & 24.75 & 1.3 & 0 & 0.171 \\
\hline 39 & 1 & 38.62 & 25.29 & 1.52 & 14 & 0.068 \\
\hline 40 & 1 & 47.02 & 25.29 & 1.85 & 36 & 0.064 \\
\hline 41 & 1 & 65.50 & 29.29 & 2.59 & 82 & 0.054 \\
\hline 42 & 1 & 29.77 & 22.37 & 1.33 & 4 & 0.058 \\
\hline 43 & 1 & 27.76 & 23.29 & 1.19 & 0 & 0.057 \\
\hline 44 & 1 & 30.2 & 28.86 & 1.44 & 10 & 0.061 \\
\hline 45 & 1 & 33.17 & 23.27 & 1.45 & 14 & 0.063 \\
\hline 46 & 1 & 31.32 & 22.28 & 1.4 & 2 & 0.065 \\
\hline 47 & 1 & 42.36 & 23.28 & 1.82 & 32 & 0.055 \\
\hline 48 & 1 & 35.2 & 19.81 & 1.77 & 24 & 0.056 \\
\hline 49 & 1 & 30.68 & 27.79 & 1.21 & 0 & 0.067 \\
\hline 50 & 1 & 27.25 & 22.37 & 1.2 & 0 & 0.054 \\
\hline
\end{tabular}


TABle 2: Continued.

\begin{tabular}{|c|c|c|c|c|c|c|}
\hline Subject & $\begin{array}{l}\text { Studied groups } \\
(0=\text { control } \\
1=\text { vendors } \\
2=\text { floriculturists })\end{array}$ & $\begin{array}{l}\text { Length } \\
(\mu \mathrm{m})\end{array}$ & $\begin{array}{l}\text { Width } \\
(\mu \mathrm{m})\end{array}$ & $\begin{array}{l}\mathrm{T} / \mathrm{N} \\
\text { index }\end{array}$ & $\begin{array}{l}\text { Cells with } \\
\text { migration } \\
(\%)\end{array}$ & $\mathrm{H}$ \\
\hline 51 & 1 & 44.15 & 23.28 & 2.23 & 64 & 0.062 \\
\hline 52 & 1 & 32.18 & 22.79 & 1.41 & 4 & 0.049 \\
\hline 53 & 1 & 41.61 & 23.84 & 1.74 & 22 & 0.057 \\
\hline 54 & 1 & 29.27 & 22.35 & 1.33 & 0 & 0.071 \\
\hline 55 & 1 & 42.08 & 24.28 & 1.73 & 22 & 0.062 \\
\hline 56 & 1 & 31.32 & 22.28 & 1.4 & 8 & 0.067 \\
\hline 57 & 1 & 26.74 & 25.82 & 1.04 & 0 & 0.056 \\
\hline 58 & 1 & 32.19 & 23.84 & 1.35 & 2 & 0.059 \\
\hline 59 & 1 & 27.76 & 21.19 & 1.3 & 2 & 0.068 \\
\hline 60 & 1 & 29.21 & 21.28 & 1.2 & 0 & 0.065 \\
\hline 61 & 1 & 24.92 & 20.77 & 1.2 & 0 & 0.066 \\
\hline 62 & 1 & 34.16 & 27.72 & 1.23 & 6 & 0.059 \\
\hline 63 & 1 & 30.23 & 26.73 & 1.13 & 0 & 0.063 \\
\hline 64 & 1 & 28.47 & 25.23 & 1.13 & 0 & 0.061 \\
\hline 65 & 1 & 35.67 & 24.38 & 1.46 & 6 & 0.066 \\
\hline 66 & 1 & 34.74 & 24.75 & 1.4 & 12 & 0.068 \\
\hline 67 & 1 & 35.45 & 22.23 & 1.59 & 14 & 0.069 \\
\hline 68 & 1 & 33.17 & 26.74 & 1.24 & 2 & 0.058 \\
\hline 69 & 1 & 42.11 & 27.3 & 1.54 & 14 & 0.053 \\
\hline 70 & 1 & 22.23 & 19.33 & 1.5 & 8 & 0.057 \\
\hline 71 & 1 & 35.15 & 24.77 & 1.41 & 4 & 0.062 \\
\hline 72 & 1 & 32.18 & 24.26 & 1.32 & 2 & 0.061 \\
\hline 73 & 1 & 36.69 & 25.74 & 1.42 & 4 & 0.064 \\
\hline 74 & 1 & 31.2 & 24.26 & 1.28 & 0 & 0.063 \\
\hline 75 & 1 & 32.69 & 23.27 & 1.4 & 12 & 0.061 \\
\hline 76 & 1 & 32.18 & 23.95 & 1.35 & 0 & 0.065 \\
\hline 77 & 1 & 30.04 & 19.21 & 1.72 & 18 & 0.064 \\
\hline 78 & 1 & 34.85 & 19.15 & 1.82 & 24 & 0.071 \\
\hline 79 & 1 & 38.64 & 19.31 & 2 & 32 & 0.068 \\
\hline 80 & 1 & 30.75 & 20.10 & 1.53 & 6 & 0.065 \\
\hline 81 & 1 & 38.12 & 21.29 & 1.79 & 12 & 0.067 \\
\hline 82 & 1 & 34.65 & 23.27 & 1.48 & 4 & 0.059 \\
\hline 83 & 1 & 33.17 & 27.72 & 1.19 & 0 & 0.065 \\
\hline 84 & 1 & 31.69 & 36.81 & 1.18 & 0 & 0.067 \\
\hline 85 & 2 & 43.02 & 25.37 & 1.68 & 18 & 0.189 \\
\hline 86 & 2 & 36.15 & 23.77 & 1.52 & 12 & 0.181 \\
\hline 87 & 2 & 23.13 & 17.93 & 1.3 & 4 & 0.179 \\
\hline 88 & 2 & 73.67 & 28.12 & 2.62 & 60 & 0.178 \\
\hline 89 & 2 & 50.71 & 25.23 & 2.01 & 38 & 0.185 \\
\hline 90 & 2 & 65.02 & 24.28 & 2.68 & 80 & 0.191 \\
\hline 91 & 2 & 27.76 & 21.29 & 2.11 & 44 & 0.178 \\
\hline 92 & 2 & 45.43 & 24.77 & 1.3 & 4 & 0.195 \\
\hline 93 & 2 & 45.45 & 24.77 & 1.82 & 40 & 0.183 \\
\hline 94 & 2 & 30.4 & 20.39 & 1.49 & 6 & 0.193 \\
\hline 95 & 2 & 39.19 & 27.74 & 1.41 & 2 & 0.176 \\
\hline 96 & 2 & 50.02 & 23.31 & 2.13 & 46 & 0.186 \\
\hline 97 & 2 & 33.17 & 26.74 & 1.24 & 2 & 0.175 \\
\hline 98 & 2 & 22.28 & 20.39 & 1.07 & 4 & 0.187 \\
\hline 99 & 2 & 29.27 & 25.75 & 1.13 & 2 & 0.192 \\
\hline 100 & 2 & 35.77 & 22.78 & 1.57 & 12 & 0.176 \\
\hline
\end{tabular}


TABle 2: Continued.

\begin{tabular}{|c|c|c|c|c|c|c|}
\hline Subject & $\begin{array}{l}\text { Studied groups } \\
(0=\text { control } \\
1=\text { vendors } \\
2=\text { floriculturists })\end{array}$ & $\begin{array}{c}\text { Length } \\
(\mu \mathrm{m})\end{array}$ & $\begin{array}{l}\text { Width } \\
(\mu \mathrm{m})\end{array}$ & $\begin{array}{l}\mathrm{T} / \mathrm{N} \\
\text { index }\end{array}$ & $\begin{array}{l}\text { Cells with } \\
\text { migration } \\
(\%)\end{array}$ & $\mathrm{H}$ \\
\hline 101 & 2 & 33.18 & 23.27 & 1.45 & 10 & 0.174 \\
\hline 102 & 2 & 35.67 & 22.78 & 1.56 & 8 & 0.188 \\
\hline 103 & 2 & 38.44 & 24.18 & 1.59 & 18 & 0.197 \\
\hline 104 & 2 & 39.12 & 23.31 & 1.67 & 12 & 0.171 \\
\hline 105 & 2 & 27.76 & 21.29 & 1.3 & 6 & 0.176 \\
\hline 106 & 2 & 26.85 & 21.29 & 1.26 & 4 & 0.187 \\
\hline 107 & 2 & 41.09 & 27.79 & 1.47 & 10 & 0.186 \\
\hline 108 & 2 & 34.74 & 24.75 & 1.4 & 2 & 0.185 \\
\hline 109 & 2 & 30.61 & 21.56 & 1.42 & 6 & 0.192 \\
\hline 110 & 2 & 62.90 & 23.65 & 2.66 & 18 & 0.184 \\
\hline 111 & 2 & 30.76 & 25.27 & 1.21 & 0 & 0.176 \\
\hline 112 & 2 & 50.35 & 22.58 & 2.23 & 26 & 0.193 \\
\hline 113 & 2 & 31.7 & 23.31 & 1.35 & 0 & 0.186 \\
\hline 114 & 2 & 34.17 & 24.99 & 1.36 & 4 & 0.178 \\
\hline 115 & 2 & 30.73 & 25.25 & 1.21 & 2 & 0.176 \\
\hline 116 & 2 & 40.01 & 24.38 & 1.61 & 8 & 0.194 \\
\hline 117 & 2 & 47.03 & 24.37 & 1.93 & 16 & 0.181 \\
\hline 118 & 2 & 46.54 & 22.28 & 2.08 & 62 & 0.198 \\
\hline 119 & 2 & 44.45 & 22.45 & 1.98 & 44 & 0.189 \\
\hline 120 & 2 & 61.42 & 22.3 & 2.75 & 48 & 0.196 \\
\hline 121 & 2 & 65.45 & 26.35 & 2.49 & 62 & 0.172 \\
\hline 122 & 2 & 47.78 & 23.54 & 2.03 & 42 & 0.176 \\
\hline 123 & 2 & 71.28 & 24.33 & 2.93 & 54 & 0.183 \\
\hline 124 & 2 & 48.48 & 25.12 & 1.93 & 24 & 0.194 \\
\hline 125 & 2 & 77.25 & 23.77 & 3.25 & 88 & 0.172 \\
\hline 126 & 2 & 35.77 & 22.78 & 1.57 & 16 & 0.179 \\
\hline 127 & 2 & 82.53 & 22.55 & 3.66 & 88 & 0.186 \\
\hline 128 & 2 & 35.64 & 23.27 & 1.53 & 14 & 0.189 \\
\hline 129 & 2 & 36.02 & 22.80 & 1.58 & 12 & 0.182 \\
\hline 130 & 2 & 49.42 & 25.61 & 1.93 & 36 & 0.187 \\
\hline 131 & 2 & 65.35 & 26.35 & 2.49 & 58 & 0.183 \\
\hline 132 & 2 & 57.32 & 21.88 & 2.62 & 74 & 0.189 \\
\hline 133 & 2 & 43.73 & 22.66 & 1.93 & 38 & 0.179 \\
\hline 134 & 2 & 43.57 & 24.26 & 1.76 & 20 & 0.176 \\
\hline 135 & 2 & 34.84 & 20.39 & 1.71 & 22 & 0.191 \\
\hline 136 & 2 & 64.93 & 24.41 & 2.66 & 74 & 0.188 \\
\hline
\end{tabular}

pesticides could have been degraded or eliminated at the sampling time, an assumption in agreement with the known fact that carbamic and organophosphate compounds undergo rapid biochemical degradation [1].

\section{DISCUSSION}

Exposure to pesticides has been related with various types of cancer, particularly those associated with immunity weakening, such as leukemia, Hodgkin lymphoma, and stomach and prostate malignancies $[6,19]$. A number of studies have shown that these diseases originate mainly from an accumulation of mutations. On the other hand, it is known that pesticide exposure may cause DNA and chromosome damage. For this reason and because pesticides are also used in various combinations, researchers in different countries have carried out the search for genotoxic alterations in populations that produce or use this type of chemicals. Results obtained in the present study as well as others reported thus far, regarding the effect produced by mixtures of pesticides, indicate that, in specific situations, floriculturists exposed to this type of chemicals exhibit increased levels of genotoxic damage. Although the biological significance of a median difference of 0.27 units between the vendors and the workers is not known, increases in genotoxic damage have been considered a primary factor in long-term effects, such as inflammatory disorders, carcinogenic alterations and reproductive toxicology $[6,20]$. However, genetic susceptibility and a number of 


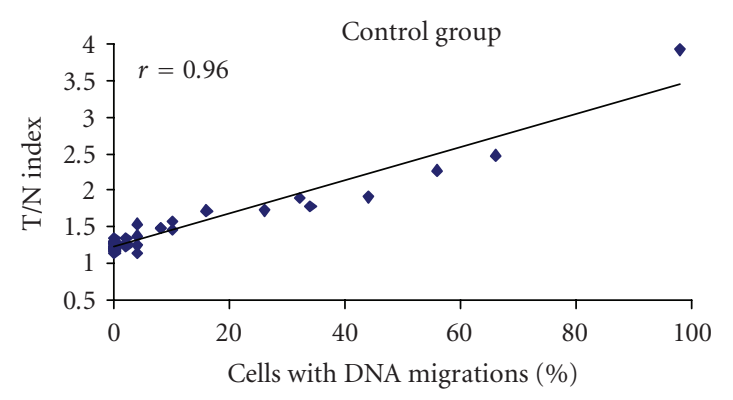

(a)

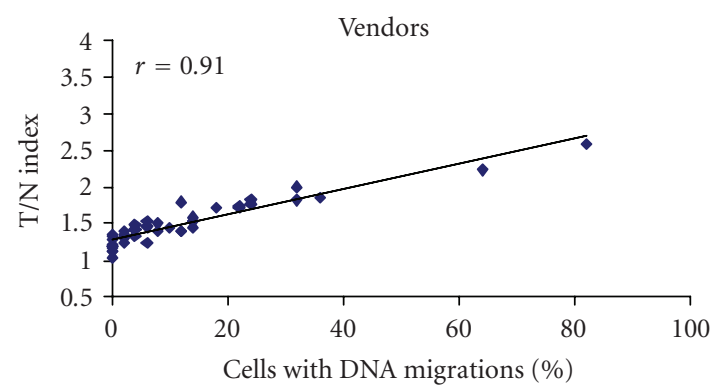

(b)

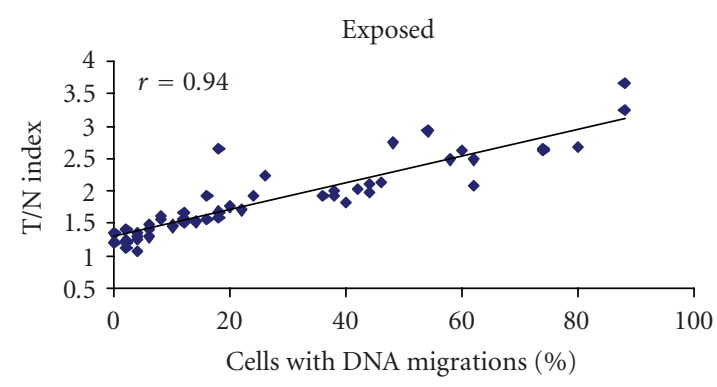

(c)

Figure 2: Correlation analyses of the $\mathrm{T} / \mathrm{N}$ index and the percentage of damaged cells in the studied groups $(\mathrm{P}<.001)$.

environmental factors seem to modulate the level of risk, as reports with negative results suggest even when the comet assay was used. Concerning pesticide exposure of flower and vegetable cultivators, the negative result reported by Piperakis et al [9], in contrast to ours, could be related with a shorter exposure time, differences in cell processing for the comet assay, and/or better protective measures in their population.

The controversial data on the genotoxic effect induced by pesticides may reflect a number of underlying differences among the populations studied, such as the test applied, the extent of exposure, the compounds involved, as well as the type and quality of the protective equipment, among others. When individuals are exposed to mixtures, it is difficult to predict the final genotoxic effect because of the interaction that could occur among the involved agents, potentiating or antagonizing the effect, besides other reasons.
TABLE 3: Effect of various characteristics of the studied groups with respect to the comet assay results ( $\mathrm{P}$ value shown). Smokers: individuals who smoke at least 5 cigarettes/day. Drinkers: individuals who consume at least $45 \mathrm{~g}$ of alcohol/day. Sex, smoking, and drinking were analyzed with the general linear model. Age and exposure years were evaluated with the Pearson's correlation test.

\begin{tabular}{lccccc}
\hline Group & Sex & Smoking & Drinking & Age & $\begin{array}{c}\text { Exposure } \\
\text { years }\end{array}$ \\
\hline Controls & 0.756 & 0.140 & 0.421 & 0.226 & - \\
Vendors & 0.414 & 0.001 & 0.013 & 0.948 & - \\
Floriculturists & 0.292 & 0.637 & 0.108 & 0.976 & 0.238 \\
\hline
\end{tabular}

For example, a higher percentage of micronuclei were observed in a subgroup of subjects using benzimidazolic compounds, compared with the micronuclei determined in individuals exposed to a complex pesticide mixture that did not include benzimidazolics [21]. However, it is interesting to note that all the pesticides that constitute the mixtures used by the floriculturists in our study have given positive results in genotoxic assays. This has been demonstrated in microorganisms and plants, insects, fishes, mice, and human cells, which were evaluated by quantifying the rate of numerical or structural chromosomal aberrations, micronuclei, SCE, or DNA breaking [22-36].

It is known that some personal characteristics and habits, mainly age, sex, or smoking, may modulate the genotoxic effect of xenobiotics, nevertheless, in the case of pesticides a conclusion is not possible as yet, because two types of results have been observed: absence of effect, or a positive correlation with respect to one or more variables [37, 38]. In the floriculturists of the present study, we found no correlation of several extrinsic variables with respect to the comet results, suggesting that the observed DNA alterations were mainly due to the effect of the pesticides. However, a pertinent observation is the low proportion of workers wearing appropriate protective devices and clothing.

With respect to the chemicals used, it is important to note that some of these have been banned in various countries because of their high toxicity. This is the case, for example, of monocrothophos and metamidophos $[39,40]$, whereas in developing countries such a prohibition process is limited because of administrative failings and the economic interests of producers who export large amounts of chemicals [19]. Finally, this type of studies can be valuable in evaluating the quality of protective measures and the possibility of substituting one or more of the applied compounds. Moreover, it has been reported that individuals working for at least six months under low levels of contamination and with appropriate protective measures could have an important reduction in their genotoxic level [41].

\section{ACKNOWLEDGMENTS}

The authors appreciate the technical assistance of the following investigators: Dr Juan Andres Burgueño Ferreira, the Bioinformatic Department, Coordinación de Investigación, 
TABLE 4: Chemicals identified in the serum of floriculturists.

\begin{tabular}{|c|c|c|c|c|}
\hline Chemical & $\begin{array}{c}\text { CAS } \\
\text { number }\end{array}$ & $\begin{array}{l}\text { Commercial } \\
\text { name }\end{array}$ & $\begin{array}{l}\text { Chemical } \\
\text { group }\end{array}$ & $\begin{array}{l}\text { Biological } \\
\text { activity }\end{array}$ \\
\hline [(benzoylamino)oxy] acetic acid & $5251-93-4$ & Topcide & Piretroid & Insecticide \\
\hline 2(3H)-benzofuranone & $1563-66-2$ & Carbofuran & Carbamate & - \\
\hline Dihydro-5pentyl-2(3H)furanone & $104-61-0$ & Furanone & Carbamate & - \\
\hline Phosphorodithioic acid, O,O, S-trimethyl ester & 2953-29-9 & Residue & Organophosphorate & - \\
\hline 1,1-biphenyl, 4,4' dichloro & $2050-68-2$ & Residue & Organochlorine & - \\
\hline Tetrachlorobiphenyl & $32598-13-3$ & Residue & Organochlorine & - \\
\hline Etilen bisditiocarbamate manganese & $12427-38-2$ & Maneb & Thiocarbamate & Fungicide \\
\hline Zinc, bis(dimethyl carbamodiate- $\left.5,5^{\prime}\right)$-(beta- 4 ) & $12122-67-7$ & Zineb & Dithiocarbamate & - \\
\hline Thiourea, ethyl & $625-53-6$ & Residue & Bis-tiocarbamate & - \\
\hline 1-benzofuran & $42969-85-7$ & Residue & Carbamate & - \\
\hline Carbamic acid, phenyl ester & $622-46-8$ & Residue & Carbamate & - \\
\hline 2,3,4,5,6-pentachloropyridine & $2176-62-7$ & PCP & Chlorinated & Herbicide \\
\hline Acetic acid, 2-ethylhexilester & $103-09-3$ & - & Additive & - \\
\hline Xylene & $106-42-3$ & - & Solvent & - \\
\hline Cyclohexanone & $108-94-1$ & - & Solvent & - \\
\hline Dimethyl phthalate & $131-11-3$ & - & Plastificant & - \\
\hline Dibutyl phthalate & $84-74-2$ & - & Plastificant & - \\
\hline Bis(2-etylhexil) phthalate & $117-81-7$ & - & Plastificant & - \\
\hline
\end{tabular}

IMSS, Marco Antonio Ramírez Olvera (M en C) and Ma. Esther Sánchez Espíndola (Biol) from the Miscroscopy Center, Escuela Nacional Ciencias Biológicas, IPN, as well as Ruth Salinas Gómez (TLQ) from the Instrumental Analysis Laboratory, Facultad de Química, Universidad Autónoma del Estado de México.

\section{REFERENCES}

[1] Klaassen CD. Casarett \& Doull's Toxicology: The Basic Science of Poisons. 6th ed. New York, NY: McGraw-Hill; 2001.

[2] Sobti RC, Krishan A, Pfaffenberger CD. Cytokinetic and cytogenetic effects of some agricultural chemicals on human lymphoid cells in vitro: organophosphates. Mutation Research/Genetic Toxicology. 1982;102(1):89-102.

[3] Bolognesi C, Peluso M, Degan P, Rabboni R, Munnia A, Abbondandolo A. Genotoxic effects of the carbamate insecticide, methyomyl. II. In vivo studies with pure compound and the technical formulation, "Lannate 25". Environmental and Molecular Mutagenesis. 1994;24(3):235-242.

[4] Debuyst B, Van Larebeke N. Induction of sister chromatid exchange in human lymphocytes by aldicarb, thiophanox and methomyl. Mutation Research/Environmental Mutagenesis and Related Subjects. 1983;113(3-4):242-243.

[5] Bonatti S, Bolognesi C, Degan P, Abbondandolo A. Genotoxic effects of the carbamate insecticide methomyl. I. In vitro studies with pure compound and the technical formulation "Lannate 25". Environmental and Molecular Mutagenesis. 1994;23(4):306-311.

[6] Bolognesi C. Genotoxicity of pesticides: a review of human biomonitoring studies. Mutation Research/Reviews in Mutation Research. 2003;543(3):251-272.
[7] Varona M, Cárdenas O, Crane C, Rocha S, Cuervo G, Vargas J. Alteraciones citogenéticas en trabajadoras con riesgo ocupacional de exposición a plaguicidas en cultivo de flores en Bogotá [Cytogenetic alterations in field workers routinely exposed to pesticides in Bogota flowers farms]. Biomédica. 2003;23(2):141-152.

[8] Bolognesi C, Landini E, Perrone E, Roggieri P. Cytogenetic biomonitoring of a floriculturist population in Italy: micronucleus analysis by Fluorescence In Situ Hybridization (FISH) with an all-chromosome centromeric probe. Mutation Research/Genetic Toxicology and Environmental Mutagenesis. 2004;557(2):109-117.

[9] Piperakis SM, Petrakou E, Tsilimigaki S, et al. Biomonitoring with the comet assay of Greek greenhouse workers exposed to pesticides. Environmental and Molecular Mutagenesis. 2003;41(2):104-110.

[10] Faust F, Kassie F, Knasmüller S, Boedecker RH, Mann M, Mersch-Sundermann V. The use of the alkaline comet assay with lymphocytes in human biomonitoring studies. Mutation Research/Reviews in Mutation Research. 2004;566(3):209-229.

[11] Tice RR, Agurell E, Anderson D, et al. Single cell gel/comet assay: guidelines for in vitro and in vivo genetic toxicology testing. Environmental and Molecular Mutagenesis. 2000; 35(3):206-221.

[12] Martínez-Tabche L, Madrigal-Bujaidar E, Negrete T. Genotoxicity and lipoperoxidation produced by paraquat and 2,4dichlorophenoxyacetic acid in the gills of rainbow trout (Oncorhynchus mikiss). Bulletin of Environmental Contamination and Toxicology. 2004;73(1):146-152.

[13] Singh NP, Danner DB, Tice RR, Brant L, Schneider EL. DNA damage and repair with age in individual human lymphocytes. Mutation Research/DNAging. 1990;237(3-4):123-130. 
[14] Bonassi S, Ceppi M, Fontana V, Merlo F. Multiple regression analysis of cytogenetic human data. Mutation Research/Environmental Mutagenesis and Related Subjects. 1994; 313(1):69-80.

[15] Lacassie E, Dreyfuss MF, Gaulier JM, Marquet P, Daguet JL, Lachâtre G. Multiresidue determination method for organophosphorus pesticides in serum and whole blood by gas chromatography-mass-selective detection. Journal of Chromatography B: Biomedical Sciences and Applications. 2001; 759(1):109-116.

[16] Barnett YA, Barnett CR. DNA damage and mutation: contributors to the age-related alterations in $\mathrm{T}$ cell-mediated immune responses? Mechanisms of Ageing and Development. 1998;102(2-3):165-175.

[17] Andreoli C, Rossi S, Leopardi P, Crebelli R. DNA damage by hydroquinone in human white blood cells: analysis by alkaline single-cell gel electrophoresis. Mutation Research/Genetic Toxicology and Environmental Mutagenesis. 1999;438(1):37-45.

[18] Environmental Protection Agency (EPA) . Guides to Pollution Prevention; The Pesticide Formulating Industry (EPA/625/790-004). Cincinnati, Ohio: EPA; 1990.

[19] Repetto RC, Baliga SS. Pesticides and the Immune System: The Public Health Risks. Washington, DC: World Resources Institute; 1996.

[20] Bilgici B, Bedir A, Şentürk N, Alvur M, Aydin F, Turanli AY. Genotoxicity assessment using comet assay in Behcet's disease patients. Mutation Research/Fundamental and Molecular Mechanisms of Mutagenesis. 2005;578(1-2):170-174.

[21] Bolognesi C, Landini E, Perrone E, Roggieri P. Cytogenetic biomonitoring of a floriculturist population in Italy: micronucleus analysis by Fluorescence In Situ Hybridization (FISH) with an all-chromosome centromeric probe. Mutation Research/Genetic Toxicology and Environmental Mutagenesis. 2004;557(2):109-117.

[22] Chauhan LK, Pant N, Gupta SK, Srivastava SP. Induction of chromosome aberrations, micronucleus formation and sperm abnormalities in mouse following carbofuran exposure. $\mathrm{Mu}$ tation Research/Genetic Toxicology and Environmental Mutagenesis. 2000;465(1-2):123-129.

[23] Elliott B. Review of the genotoxicity of 4-chloro-2-methylphenoxyacetic acid. Mutagenesis. 2005;20(1):3-13.

[24] Jablonická A, Poláková H, Karelová J, Vargová M. Analysis of chromosome aberrations and sister-chromatid exchanges in peripheral blood lymphocytes of workers with occupational exposure to the mancozeb-containing fungicide Novozir Mn80. Mutation Research/Genetic Toxicology. 1989;224(2):143-146.

[25] Soloneski S, Reigosa MA, Larramendy ML. Effect of dithiocarbamate pesticide zineb and its commercial formulation, azzurro. II. micronucleus induction in immunophenotyped human lymphocytes. Environmental and Molecular Mutagenesis. 2002;40(1):57-62.

[26] Mäki-Paakkanen J, Laaksonen M, Munter T, Kronberg L, Komulainen H. Comparable DNA and chromosome damage in Chinese hamster ovary cells by chlorohydroxyfuranones. Environmental and Molecular Mutagenesis. 2001;38(4):297-305.

[27] Padungtod C, Hassold TJ, Millie E, et al. Sperm aneuploidy among Chinese pesticide factory workers: scoring by the FISH method. American Journal of Industrial Medicine. 1999;36(2):230-238.

[28] Rupa DS, Reddy PP, Reddi OS. Cytogeneticity of quinalphos and methyl parathion in human peripheral lymphocytes. $\mathrm{Hu}$ man \& Experimental Toxicology. 1990;9(6):385-387.
[29] Ündeger Ü, Institóris L, Siroki O, Nehéz M, Dési I. Simultaneous geno-and immunotoxicological investigations for early detection of organophosphate toxicity in rats. Ecotoxicology and Environmental Safety. 2000;45(1):43-48.

[30] Amer SM, Donya SM, Aly FA. Genotoxicity of benomyl and its residues in somatic and germ cells of mice fed on treated stored wheat grains. Archives of Toxicology. 2003;77(12):712721.

[31] Bentley KS, Kirkland D, Murphy M, Marshall R. Evaluation of thresholds for benomyl-and carbendazim-induced aneuploidy in cultured human lymphocytes using Fluorescence In Situ Hybridization. Mutation Research/Genetic Toxicology and Environmental Mutagenesis. 2000;464(1):41-51.

[32] Dolara P, Salvadori M, Capobianco T, Torricelli F. Sisterchromatid exchanges in human lymphocytes induced by dimethoate, omethoate, deltamethrin, benomyl and their mixture. Mutation Research Letters. 1992;283(2):113-118.

[33] Kalantzi OI, Hewitt R, Ford KJ, et al. Low dose induction of micronuclei by lindane. Carcinogenesis. 2004;25(4):613-622.

[34] Saleha Banu B, Danadevi K, Rahman MF, Ahuja YR, Kaiser J. Genotoxic effect of monocrotophos to sentinel species using comet assay. Food and Chemical Toxicology. 2001;39(4):361366.

[35] Jamil K, Shaik AP, Mahboob M, Krishna D. Effect of organophosphorus and organochlorine pesticides (monochrotophos, chlorpyriphos, dimethoate, and endosulfan) on human lymphocytes in-vitro. Drug and Chemical Toxicology. 2004;27(2): 133-144.

[36] Mahboob M, Rahman MF, Danadevi K, Saleha Banu B, Grover P. Detection of DNA damage in mouse peripheral blood leukocytes by the comet assay after oral administration of monocrotophos. Drug and Chemical Toxicology. 2002;25(1):65-74.

[37] Zeljezic D, Garaj-Vrhovac V. Chromosomal aberration and single cell gel electrophoresis (Comet) assay in the longitudinal risk assessment of occupational exposure to pesticides. Mutagenesis. 2001;16(4):359-363.

[38] Grover P, Danadevi K, Mahboob M, Rozati R, Saleha Banu B, Rahman MF. Evaluation of genetic damage in workers employed in pesticide production utilizing the Comet assay. $\mathrm{Mu}$ tagenesis. 2003;18(2):201-205.

[39] Arévila A, Ramos J, Jiménez B. Evaluación de la contaminación dispersa por agroquímicos en México. Ingeniería Ambiental. 1997;1:26-30.

[40] Finkelman J. Epidemiología Ambiental: Un proyecto para América Latina y el Caribe. lera ed. México: Organización Panamericana de la Salud y Organización Mundial de la Salud; 1994.

[41] Carbonell E, Valbuena A, Xamena N, Creus A, Marcos R. Temporary variations in chromosomal aberrations in a group of agricultural workers exposed to pesticides. Mutation Research/Genetic Toxicology. 1995;344(3-4):127-134. 

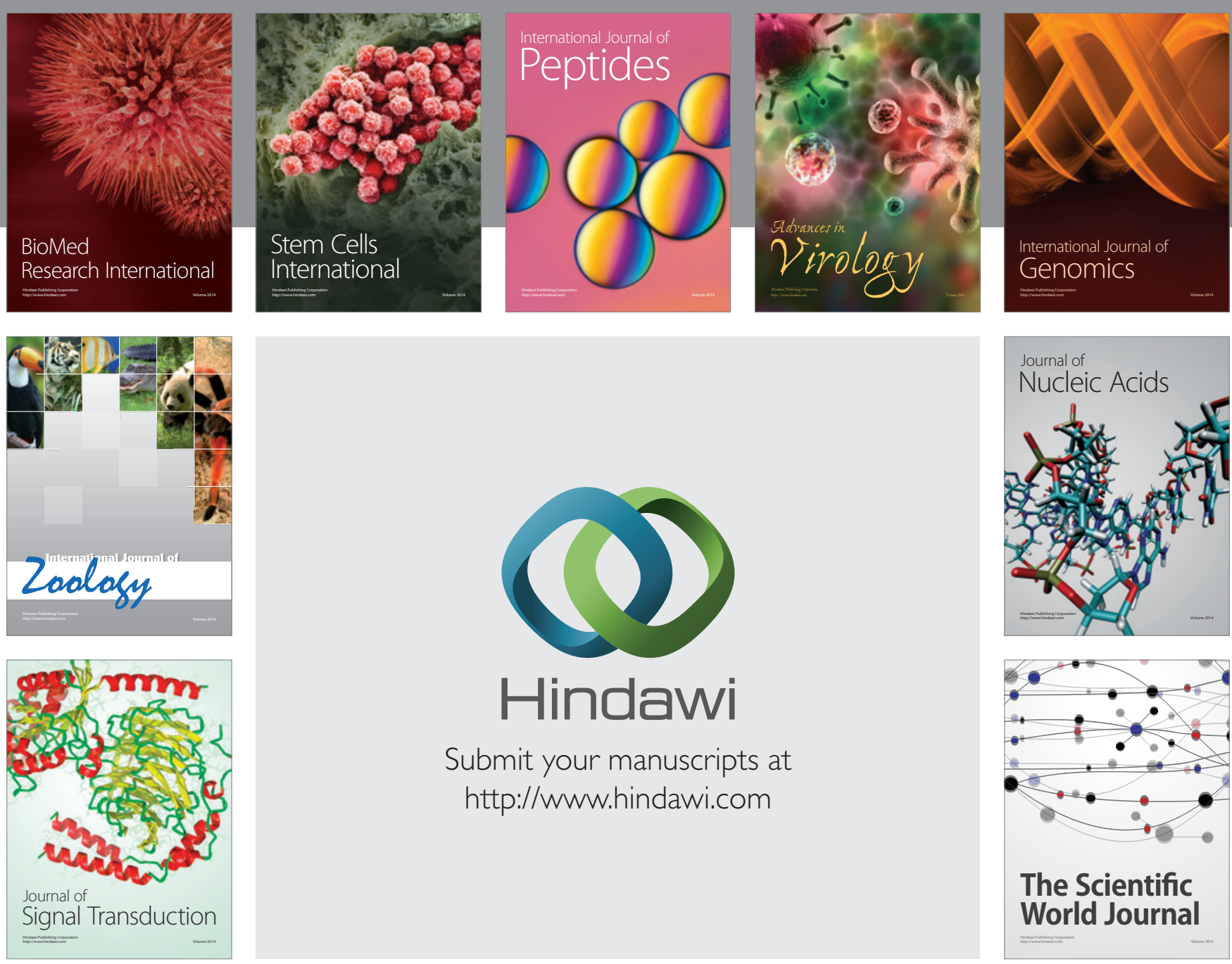

Submit your manuscripts at

http://www.hindawi.com
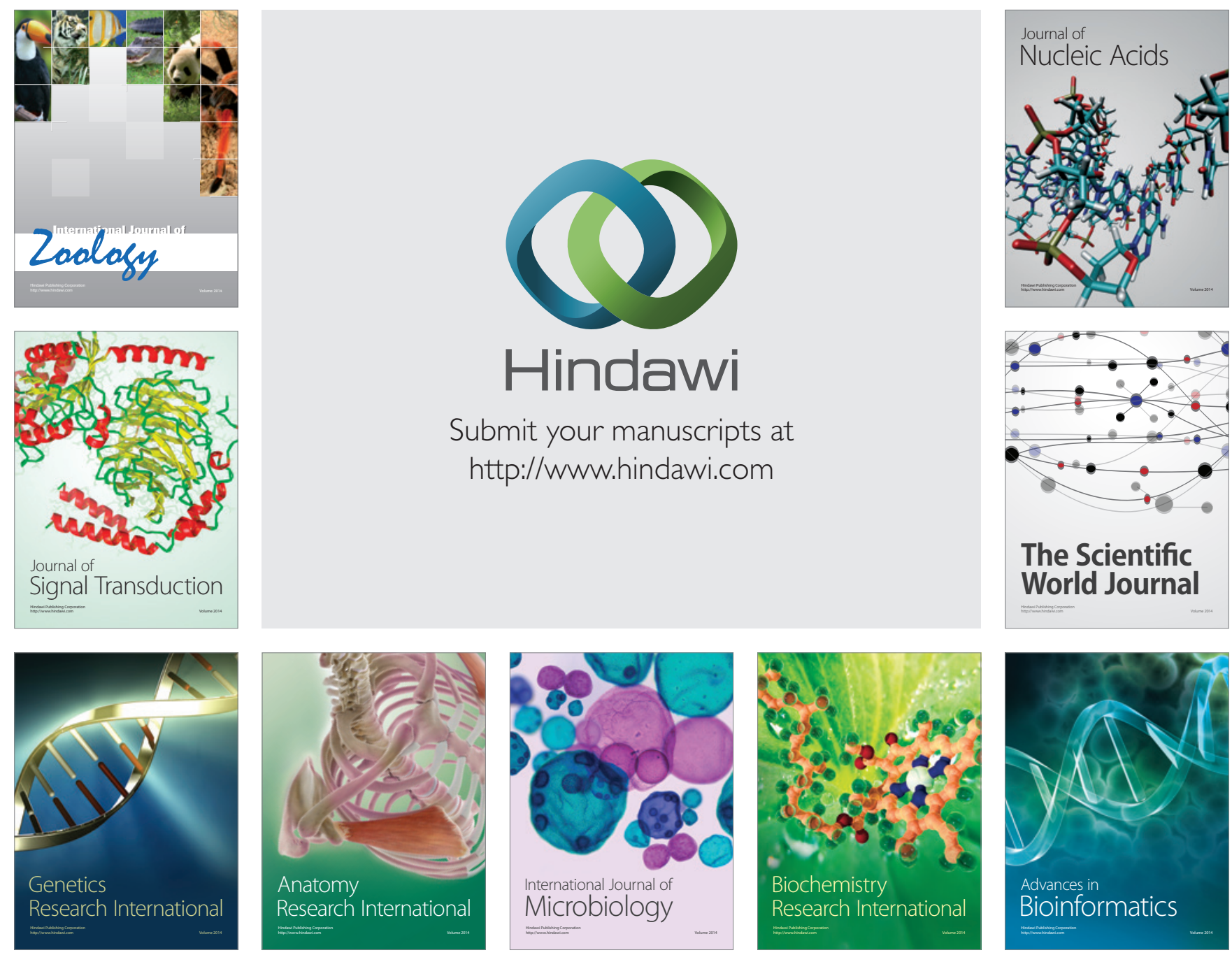

The Scientific World Journal
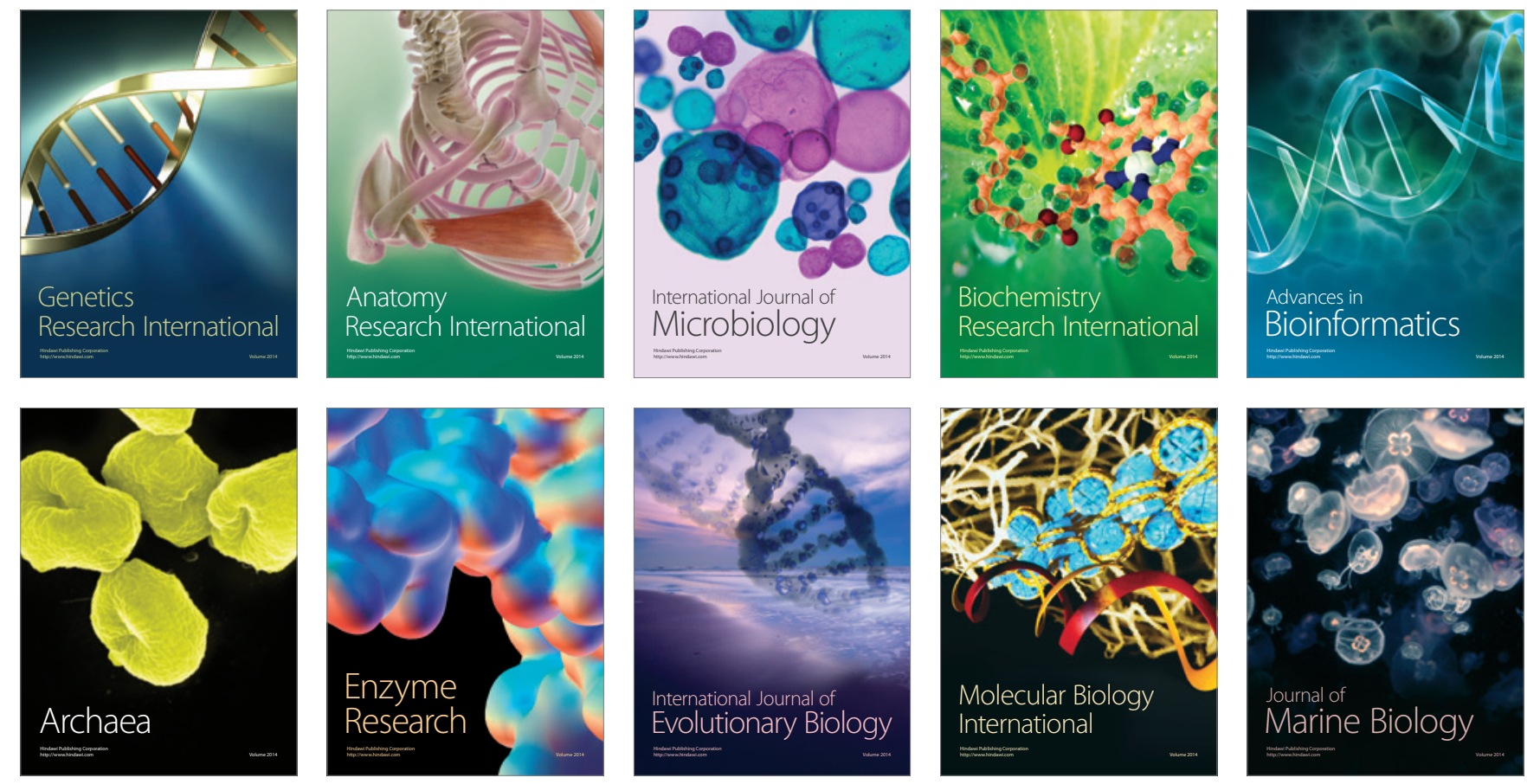